\title{
Inheritance of seed coat color in sesame
}

\author{
Hernán Laurentin ${ }^{(1)}$ and Tonis Benítez ${ }^{(1)}$ \\ (1)Universidad Centroccidental Lisandro Alvarado, Decanato de Agronomía, Departamento de Ciencias Biológicas, Vía Agua Viva, \\ Cabudare 3023, Venezuela. E-mail: hlaurentin@ucla.edu.ve, tonisbenitez@hotmail.com
}

\begin{abstract}
The objective of this work was to determine the inheritance mode of seed coat color in sesame. Two crosses and their reciprocals were performed: UCLA37 x UCV3 and UCLA90 x UCV3, of which UCLA37 and UCLA90 are white seed, and UCV3 is brown seed. Results of reciprocal crosses within each cross were identical: $F_{1}$ seeds had the same phenotype as the maternal parent, and $F_{2}$ resulted in the phenotype brown color. These results are consistent only with the model in which the maternal effect is the responsible for this trait. This model was validated by recording the seed coat color of $100 \mathrm{~F}_{2}$ plants $\left(\mathrm{F}_{3}\right.$ seeds $)$ from each cross with its reciprocal, in which the 3:1 expected ratio for plants producing brown and white seeds was tested with the chi-square test. Sesame seed color is determined by the maternal genotype. Proposed names for the alleles participating in sesame seed coat color are: $\mathrm{Sc}_{1}$, for brown color; and $\mathrm{Sc}_{2}$, for white color; $\mathrm{Sc}_{1}$ is dominant over $\mathrm{Sc}_{2}$.
\end{abstract}

Index terms: Sesamum indicum, export market, maternal effect, seed color, sesame breeding.

\section{Herança da cor do tegumento em sementes de gergelim}

Resumo - O objetivo deste trabalho foi determinar o padrão de herança da cor do tegumento da semente de gergelim. Dois cruzamentos com recíprocos foram feitos: UCLA37 x UCV3 e UCLA90 x UCV3, dos quais UCLA37 e UCLA90 apresentam sementes brancas e UCV3, sementes marrons. Os resultados dos cruzamentos recíprocos, dentro de cada cruzamento, foram idênticos: as sementes $F_{1}$ mostraram o mesmo fenótipo que o parental materno, e as $\mathrm{F}_{2}$ resultaram no fenótipo semente marrom. Esses resultados são consistentes apenas com o modelo no qual o efeito materno é responsável por essa característica. Esse modelo foi validado pelo registro da cor do tegumento da semente de 100 plantas $\mathrm{F}_{2}$ (sementes $\mathrm{F}_{3}$ ) para cada cruzamento com o seu recíproco, em que a proporção esperada de 3:1 para plantas produzindo sementes marrons e brancas foi testada com o teste do qui-quadrado. A cor do tegumento da semente de gergelim é determinada pelo genótipo materno. Os nomes propostos para os alelos participantes na determinação da cor da semente de gergelim são: $\mathrm{Sc}_{1}$, para a cor marrom; e $\mathrm{Sc}_{2}$, para a cor branca; $\mathrm{Sc}_{1}$ é dominante sobre $\mathrm{Sc}_{2}$.

Termos para indexação: Sesamum indicum, mercado de exportação, efeito materno, cor da semente, melhoramento de gergelim.

\section{Introduction}

Sesame (Sesamum indicum L.) is an important cultivated species in tropical areas. It is mainly used as a source of high-quality edible oil and for different types of direct consumption (Laurentin \& Karlosvky, 2006). According to Food and Agriculture Organization of the United Nations (2013), the average annual production in the last ten years has been over 4 million tons. Myanmar, India, China, Ethiopia, and Nigeria are the major producers worldwide. About $25 \%$ of their production is export-driven and mainly sent to China, Japan, Turkey, Korea, and Syria. Sesame production in Latin America is also oriented to exportation. Paraguay, Guatemala, Mexico, Bolivia, and Venezuela are the major exporter countries in the region and are responsible for about $10 \%$ of the international market. The most exported agricultural product in Venezuela is represented by sesame grains.

One of the most important attributes for introducing sesame grains in the market is seed color. Although most are light colored (Morris, 2009), there is a wide variability in sesame seed coat color, which varies from white to black. Due to the importance of this trait for the export market, seed color is a central target in sesame breeding programs; however, there are few studies on the inheritance of this essential seed attribute, and determination of genetic factors affecting any trait is necessary to establish useful breeding programs. 
The inheritance of traits may be explained in three ways by: nuclear inheritance, attributed to genes in the nucleus; cytoplasmic inheritance, due to genes in the mitochondria or chloroplast; and maternal effect, which is the effect of the mother plant on some progeny phenotypes, especially on seeds (Laurentin, 2011). A comprehensive inheritance study must consider reciprocal crosses, to compare $F_{1}$ and $F_{2}$ progenies coming from different maternal genotypes.

Previous inheritance studies about seed coat color in sesame report different inheritance mechanisms. Gutiérrez et al. (1994), Falusi (2007), and Zhang et al. (2013) concluded that inheritance was controlled by major genes at the cell nucleus. Shim et al. (2005) and Ashri (2006) reported that minor genes were the ones responsible for this trait; however Ashri (2006) also observed that the white color was a recessive character. None of these investigations used reciprocal crosses. Pandey et al. (2013), using reciprocal crosses, found that the maternal effect is responsible for the inheritance of seed coat color; however, these authors did not compare $\mathrm{F}_{2}$ and reciprocal $\mathrm{F}_{2}$; therefore, doubt remains if this result is due to maternal effect or cytoplasmic inheritance.

The objective of this work was to determine the inheritance mode of seed coat color in sesame.

\section{Materials and Methods}

The experiment was carried out at the Miguel Luna Lugo Experimental Station, at Universidad Centroccidental Lisandro Alvarado, in Cabudare, state of Lara, Venezuela $\left(10^{\circ} 01^{\prime} 25^{\prime \prime} \mathrm{N}, 69^{\circ} 16^{\prime} 44^{\prime \prime} \mathrm{W}\right.$, at $510 \mathrm{~m}$ above sea level), in 2011 and 2012 (one cycle per year). The region has silty-clay-loam soils and an annual average rainfall of $750 \mathrm{~mm}$.

Two cultivars, UCLA37 and UCLA90 (Laurentin et al., 2004), were used as white-seed genes donors; and the cultivar UCV3 (Laurentin et al., 2004) was used as a brown-seed gene donor. Individual plants from the two white-seed cultivars, UCLA37 and UCLA90, were crossed reciprocally to individual plants of the brown-seed cultivar, UCV3. Crosses were made at plant maturity by placing fresh pollen on the stigma tip of a flower emasculated 12 hours before. In this way, four $F_{1}$ populations were obtained: the first one from UCLA37 as the female parent crossed to UCV3 as the male parent; the second one by the reciprocal cross of UCLA37 as the male parent to UCV3 as the female parent; the third one using UCLA90 as the female parent crossed to UCV3 as the male parent; and the fourth one by the reciprocal cross of UCLA90 as the male parent to UCV3 as the female parent. Five seeds of each $F_{1}$ generation were sown to get $F_{1}$ plants and $F_{2}$ seeds by natural self-pollination.

For each of the four populations, for both generations $\left(F_{1}\right.$ and $\left.F_{2}\right)$, color seed was recorded for each individual seed. Observed values within each population in each generation were compared to the expected values for: one-gene nuclear inheritance; cytoplasmic inheritance; and maternal effect by means of a chi-square $\left(\chi^{2}\right)$ goodness of fit test. Null hypothesis for $F_{1}$ and $F_{2}$ must be that all individuals had only one phenotype, and alternative hypothesis, that individuals had different phenotypes; however, because the $\chi^{2}$ test requires at least two phenotypes, hypothesis was tested arbitrarily with $99 \%$ of individuals for one phenotype and with $1 \%$ of individuals for another phenotype. This information was complemented with the comparison between $F_{1}$ and reciprocal $F_{1}$, and also between $F_{2}$ and reciprocal $F_{2}$. Phenotypic designation of each generation and comparison between populations were done for both crosses. The dichotomous key used for determining the inheritance mode of seed color is described in Table 1 . To validate the model, $100 \mathrm{~F}_{2}$ seeds from all crosses were sown, and seed color in each individual $\mathrm{F}_{2}$ plant $\left(\mathrm{F}_{3}\right.$ seeds) was recorded. $\chi^{2}$ goodness of fit test

Table 1. Dichotomous key used to determine the inheritance mode of seed coat color in sesame (Sesamum indicum).

\begin{tabular}{|c|c|c|}
\hline & Alternative results & Inheritance mode \\
\hline \multirow{2}{*}{1} & $\begin{array}{l}100 \% \text { of individuals with the same phenotype within each } F_{1}\left(F_{1} \text { and reciprocal } F_{1}\right) \text {, and both } F_{1} \text { 's }\left(F_{1} \text { and }\right. \\
\left.\text { reciprocal } F_{1}\right) \text { with the same phenotype. }\end{array}$ & Nuclear inheritance \\
\hline & $\begin{array}{l}100 \% \text { of individuals with the same phenotype within each } F_{1}\left(F_{1} \text { and reciprocal } F_{1}\right) \text {, but both } F_{1} \text { 's }\left(F_{1} \text { and }\right. \\
\left.\text { reciprocal } F_{1}\right) \text { with different phenotypes. }\end{array}$ & 2 \\
\hline \multirow{2}{*}{2} & $\begin{array}{l}100 \% \text { of individuals with the same phenotype within each } \mathrm{F}_{2}\left(\mathrm{~F}_{2} \text { and reciprocal } \mathrm{F}_{2}\right) \text {, and both } \mathrm{F}_{2} \text { 's }\left(\mathrm{F}_{2} \text { and }\right. \\
\left.\text { reciprocal } \mathrm{F}_{2}\right) \text { with the same phenotype. }\end{array}$ & Maternal effect \\
\hline & $\begin{array}{l}100 \% \text { of individuals with the same phenotype within each } \mathrm{F}_{2}\left(\mathrm{~F}_{2} \text { and reciprocal } \mathrm{F}_{2}\right) \text {, but both } \mathrm{F}_{2} \text { 's }\left(\mathrm{F}_{2} \text { and }\right. \\
\left.\text { reciprocal } \mathrm{F}_{2}\right) \text { with different phenotypes. }\end{array}$ & Cytoplasmic inheritance \\
\hline
\end{tabular}


was performed for comparison of the observed and expected phenotype ratios according to the determined inheritance mode. All $\chi^{2}$ tests were performed with the software Genes, version 4.1 (CNPq and UFV, Viçosa, MG, Brazil).

\section{Results and Discussion}

$\mathrm{F}_{1}$ phenotypes were defined by recording coat color of individual seeds and using the $\chi^{2}$ test (Table 2). For the four $\mathrm{F}_{1}$ generations, null hypothesis was accepted, since $100 \%$ of the individuals within each $\mathrm{F}_{1}$ had the same phenotype. Crosses + UCLA37 x ${ }^{\wedge} \mathrm{UCV} 3$ and +UCLA90 $\mathrm{x}$ ठैUCV3 resulted in the phenotype white seed coat; however, crosses $९$ UCV3 x ठ UCLA37 and qUCV3 x ${ }^{1} \mathrm{UCLA} 90$ resulted in the phenotype brown seed coats. As for $F_{1}$, null hypothesis was accepted for the four $F_{2}$, since $100 \%$ of the individuals within each $\mathrm{F}_{2}$ resulted in the same brown seed coat phenotype (Table 2). Comparison between $\mathrm{F}_{1}$ of UCLA37 $\mathrm{x}$ UCV3 and $F_{1}$ from its reciprocal crosses resulted in different phenotypes; the same was recorded for $F_{1}$ of UCLA90 x UCV3 and its reciprocal. Laurentin (2011) attributes these results to the influence of the maternal genotype. Similar results have been reported in several species and traits; for example, in interspecific hybrids of Passiflora for vegetative traits (Primot et al., 2005), or in the composition of fatty acids in soybean (Glycine max L.) seeds (Gilsinger et al., 2010).
When UCLA37 was the female parent, $\mathrm{F}_{1}$ had white seeds, but in the reciprocal cross, when UCV3 acted as the female parent, seed coats were a brown color. Similarly, in the cross UCLA90 x UCV3, F 1 resulted in white seeds when UCLA90 was the female parent; however, when UCV3 was the female parent, the seed coats were brown. For both crosses, the phenotype depended on the female parent. These results discard nuclear inheritance for this trait, and results on $\mathrm{F}_{2}$ must be analyzed to determine if maternal effect or cytoplasmic inheritance are occurring (Table 1). For both crosses, $\mathrm{F}_{2}$ resulted in brown seeds, independently of which parent was acting as the female parent in the original cross. When the maternal effect is determining the inheritance of a trait, there is a causal influence of the maternal genotype or phenotype on the offspring phenotype (Wolf \& Wade, 2009). A possible explanation is that for both $\mathrm{F}_{2}$ generations within each cross (the cross and its reciprocal cross), offspring have different cytoplasmic content, but maternal parents have the same nuclear genotype.

The presence of only one phenotype within each generation for both crosses suggests that major genes, located in the mother plant, are determining seed coat color. Therefore, the identification of these genes has been proposed according to seed color ( $\mathrm{Sc}$ ), using numbers to indicate different alleles; the genotype of $\mathrm{UCV} 3$ has been identified as $\mathrm{Sc}_{1} \mathrm{Sc}_{1}$, and the genotypes of UCLA37 and UCLA90 as $\mathrm{Sc}_{2} \mathrm{Sc}_{2}$. Pandey et al.

Table 2. Phenotypes and seed number obtained for $F_{1}$ and $F_{2}$ seeds, and for $F_{2}$ plants ( $F_{3}$ seeds) from crosses between UCLA37 and UCV3, and between UCLA90 and UCV3 sesame (Sesamum indicum) cultivars.

\begin{tabular}{|c|c|c|c|c|c|}
\hline \multirow[t]{2}{*}{ Crosses } & \multirow[t]{2}{*}{ Seed number for $F_{1}$} & \multicolumn{2}{|c|}{ Number of seeds with color } & \multirow[t]{2}{*}{ Calculated chi-square } & \multirow[t]{2}{*}{ p-value } \\
\hline & & White & Brown & & \\
\hline & \multicolumn{5}{|c|}{$\mathrm{F}_{1}$ and reciprocal $\mathrm{F}_{1}$} \\
\hline qUCLA37 x đUCV3 & 182 & 182 & 0 & 0 & 0.32 \\
\hline qUCV3 x §̋UCLA37 & 137 & 0 & 137 & 0 & 0.32 \\
\hline qUCLA90 x đ̆UCV3 & 199 & 197 & 2 & 1.00 & 0.31 \\
\hline \multirow[t]{2}{*}{ qUCV3 x ठUCLA90 } & 176 & 176 & 176 & 0 & 0.32 \\
\hline & \multicolumn{5}{|c|}{$\mathrm{F}_{2}$ and reciprocal $\mathrm{F}_{2}$} \\
\hline qUCLA37 x 3 UCV3 & 217 & 0 & 217 & 0 & 0.32 \\
\hline †UCV3 x ठ̋UCLA37 & 433 & 0 & 433 & 0 & 0.32 \\
\hline †UCLA90 x ð̂UCV3 & 431 & 0 & 431 & 0 & 0.32 \\
\hline \multirow[t]{2}{*}{ QUCV3 x §̋ULLA90 } & 411 & 0 & 411 & 0 & 0.32 \\
\hline & \multicolumn{5}{|c|}{$\mathrm{F}_{2}$ plants $\left(\mathrm{F}_{3}\right.$ seeds $)$} \\
\hline qUCLA37 x 3 UCV3 & 100 & 33 & 67 & 3.41 & 0.06 \\
\hline ૧UCV3 x §̋UCLA37 & 100 & 31 & 69 & 1.92 & 0.17 \\
\hline †UCLA90 x §̂UCV3 & 100 & 20 & 80 & 1.33 & 0.24 \\
\hline †UCV3 x ðैUCLA90 & 100 & 29 & 71 & 0.85 & 0.35 \\
\hline
\end{tabular}


(2013) suggested names to describe genes that determine seed coat color; however, they did not evaluate phenotypes obtained in reciprocal crosses, or record phenotypes of the two $F_{2}$ generations, only of one $\mathrm{F}_{2}$ per cross. The results obtained by these authors in $F_{1}$ and reciprocal $F_{1}$ agree with those of the present work, but it is not possible to discern if the trait is under maternal effect or cytoplasmic inheritance because of the lack of results from both $\mathrm{F}_{2}$.

Seed phenotype was determined by the genotype of the mother plant, not by the cytoplasmic content or the genotype of the seed itself (Figure 1). When the mother plant presented a homozygous $\mathrm{Sc}_{1}$ allele, $\mathrm{F}_{1}$ seeds were brown; when the mother plant presented a homozygous $\mathrm{Sc}_{2}$ allele, $\mathrm{F}_{1}$ seeds were white. Likewise, for $\mathrm{F}_{2}$, seed color was determined by the mother plant genotype; and, since both genotypes were the same, both phenotypes were also the same. For $F_{1}$ plants (that carried $\mathrm{F}_{2}$ seeds), the $\mathrm{Sc}_{1}$ allele was dominant over the $\mathrm{Sc}_{2}$ allele; therefore, both $\mathrm{F}_{2}$ resulted in brown coat seeds. To validate the model, $100 \mathrm{~F}_{2}$ plants were obtained for each of the four populations, and seed coat color was recorded for each individual plant. If the maternal effect is responsible for seed coat color, $75 \%$ of the $\mathrm{F}_{2}$ plants must produce brown seeds and $25 \%$ of the $\mathrm{F}_{2}$ plants must produce white seeds (Figure 1). The $\chi^{2}$ test was used to verify this hypothesis (Table 2 ).

According to most of the previous studies on the inheritance of sesame seed coat color, this trait is determined by major genes at the embryo (Gutiérrez et al., 1994; Ashri, 2006; Falusi, 2007; Zhang et al., 2013). Although these reports did not present results of reciprocal crosses, it is possible to conclude that there was segregation for $F_{2}$, which discards the maternal effect. The results obtained in the present study also show that major genes are responsible for sesame seed coat color and for the dominance of dark color over light color, but differ strongly as to the inheritance mode. Only Pandey et al. (2013) indicate that maternal effect controls sesame seed coat color; however, the authors do not discuss this result. That could be explained by the different genetic background of the plant material used, which originates a different inheritance mechanism due to the presence of a single locus controlling the mechanism of this maternal influence, such as the one proposed by Wolf \&

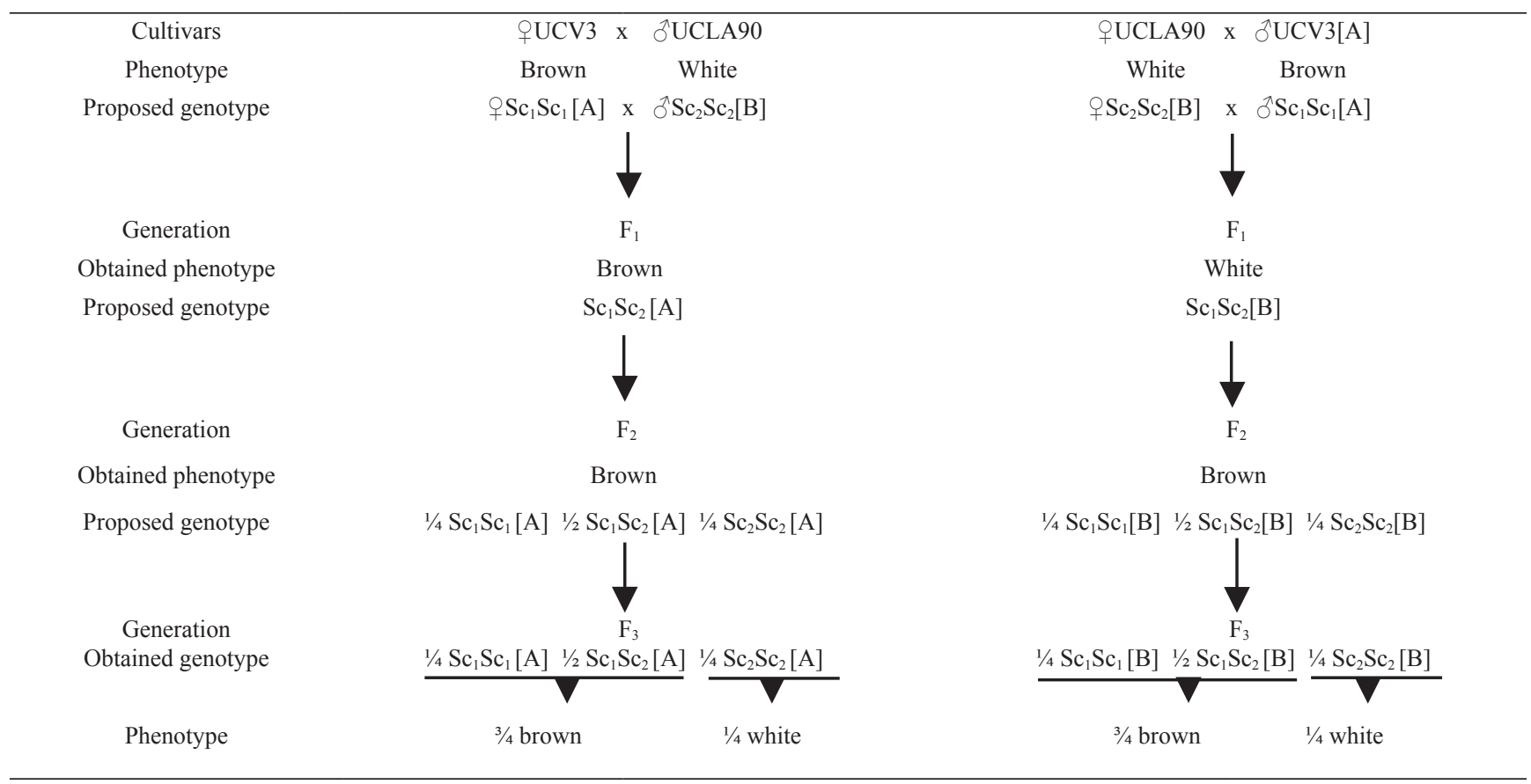

Figure 1. Proposed model to explain the maternal effect on seed coat color when UCLA90 was crossed to UCV3, and when UCLA37 was crossed to UCV3, both reciprocally. $\mathrm{Sc}_{1}$ and $\mathrm{Sc}_{2}$ represent nuclear alleles; [A] and [B] represent cytoplasmic content. The model shows that phenotype differences are a consequence of the maternal genotype and are not related to nuclear genotype or to cytoplasmic content. 
Wade (2009): pre-loading of messenger RNAs into the unfertilized ovule, or nutritional provision from mother plant to zygote. In a similar way, Gilsinger et al. (2010) explained maternal effect on fatty acid composition of soybean seeds as a consequence of factors translocated from the maternal plant. The presence of this allele in a maternal plant would originate a maternal effect, promoting the transport of proteins or mRNA by another gene (in this case Sc) to the zygote, determining maternally the seed coat color. When the allele is not present in the maternal plant, seed coat color would be determined by the genotype of the own zygote, as is the case in previous studies. Different inheritance modes for seed color have been described for other cultivated species; for instance, in Brassica campestris, it has been found that this trait is determined by nuclear genes (Stringam, 1980), but also by the maternal effect (Chen \& Heneem, 1992). Rahman et al. (2001) reported inheritance in B. napus due to nuclear genes; however, Liu et al. (2005) also observed maternal effect. In soybean, Terao (1918) obtained a result that adjusts to the proposed model of inheritance, in which a major gene is responsible for maternal effect, concluding that a single factor is responsible for green seed coat color when the maternal parent was yellow, but that there was no segregation when the maternal parent was green, since $F_{1}$ and $F_{2}$ were the same color as the female parent.

The results obtained in the present study, which contradict those of previous reports, indicate that the inheritance pattern for seed coat color in sesame depends on the genetic background of the genotypes acting as parents. Therefore, it is necessary to determine the inheritance mode for this trait for parents, which will be used to obtain segregant populations, when seed coat color is the target in sesame breeding.

\section{Conclusions}

1. The inheritance mode of seed coat color in sesame (Sesamum indicum) observed for the two crosses evaluated - UCLA37 x UCV3 and UCLA90 x UCV3, both reciprocally -, is the maternal effect.

2. Seed coat color in sesame is determined by the maternal genotype, in which the allele $\mathrm{Sc}_{1}$ is the code for brown color and $\mathrm{Sc}_{2}$ for white color, being $\mathrm{Sc}_{1}$ dominant over $\mathrm{Sc}_{2}$.

\section{References}

ASHRI, A. Sesame (Sesamum indicum L.). In: SINGH, R.J. (Ed.). Genetic resources, chromosome engineering, and crop improvement: oilseed crops. Boca Raton: CRC Press, 2006. v.4, p.231-279. DOI: 10.1201/9781420005363.ch8.

CHEN, B.Y.; HENEEN, W.K. Inheritance of seed color in Brassica campestris L. and breeding for yellow-seeded B. napus L. Euphytica, v.59, p.157-163, 1992. DOI: 10.1007/BF00041268.

FALUSI, O.A. Segregation of genes controlling seed colour in sesame (Sesamum indicum Linn.) from Nigeria. African Journal of Biotechnology, v.6, p.2780-2783, 2007.

FOOD AND AGRICULTURE ORGANIZATION OF THE UNITED NATIONS. FAOSTAT. Available at: $<$ http://faostat.fao. org>. Accessed on: 27 Nov. 2013.

GILSINGER, J.J.; BURTON, J.W.; CARTER JUNIOR, T.E. Maternal effects on fatty acid composition of soybean seed oil. Crop Science, v.50, p.1874-1881, 2010. DOI: 10.2135/cropsci2009.09.0553.

GUTIÉRREZ, E.; MONTEVERDE-PENSO, E.J.; QUIJADA, P. Herencia del color de la semilla y número de lóculos por cápsula en tres cultivares de ajonjolí (Sesamum indicum L.). Agronomía Tropical, v.44, p.513-527, 1994.

LAURENTIN, H. Genética agrícola. Madrid: Editorial Académica Española, 2011. 248p.

LAURENTIN, H.; KARLOVSKY, P. Genetic relationship and diversity in a sesame (Sesamum indicum L.) germplasm collection using amplified fragment length polymorphism (AFLP). BMC Genetics, v.7, p.10, 2006. DOI: 10.1186/1471-2164-7-10.

LAURENTIN, H.; MONTILLA, D.; GARCIA, V. Relación entre el rendimiento de ocho genotipos de ajonjolí (Sesamum indicum L.) y sus componentes. Comparación de metodologías. Bioagro, v.16, p.153-162, 2004.

LIU, Z.W.; FU, T.-D.; TU, J.-X.; CHEN, B.-Y. Inheritance of seed colour and identification of RAPD and AFLP markers linked to the seed colour gene in rapeseed (Brassica napus L.). Theoretical and Applied Genetics, v.110, p.303-310, 2005. DOI: 10.1007/ s00122-004-1835-1.

MORRIS, J.B. Characterization of sesame (Sesamum indicum L.) germplasm regenerated in Georgia, USA. Genetic Resources and Crop Evolution, v.56, p.925-936, 2009. DOI: 10.1007/ s10722-009-9411-9.

PANDEY, S.K.; DAS, A.; DASGUPTA, T. Genetics of seed coat color in sesame (Sesamum indicum L.). African Journal of Biotechnology, v.12, p.6061-6067, 2013. DOI: 10.5897/ AJB2013.13055.

PRIMOT, S.; D’EECKENBRUGGE, G.; RIOUX, V.; OCAMPO PÉREZ, J.A.; GARCIN, F. Variación morfológica de tres especies de curubas (Passiflora tripartita var. mollissima, P. tarminiana y P. mixta) y sus híbridos en el Valle del Cauca (Colombia). Revista Brasileira de Fruticultura, v.27, p.467-471, 2005. DOI: 10.1590/ S0100-29452005000300030.

RAHMAN, M. Production of yellow-seeded Brassica napus through interspecific crosses. Plant Breeding, v.120, p.463-472, 2001. DOI: 10.1046/j.1439-0523.2001.00640.x. 
SHIM, K.B.; LEE, Y.Y.; CHO, S.; PAE, S.B.; SUH, D.Y. Inheritance of seed coat color in sesame. Korean Journal of Breeding, v.37, p.1-4, 2005.

STRINGAM, G.R. Inheritance of seed color in turnip rape. Canadian Journal of Plant Science, v.60, p.331-335, 1980. DOI: 10.4141/cjps80-054.

TERAO, H. Maternal inheritance in the soy bean. American Naturalist, v.52, p.51-56, 1918. DOI: 10.1086/279654.
WOLF, J.B.; WADE, M.J. What are maternal effects (and what are they not)? Philosophical Transactions of the Royal Society. Biological Sciences, v.364, p.1107-1115, 2009. DOI: 10.1098/ rstb.2008.0238.

ZHANG, H.; MIAO H.; WEI L.; LI, C.; ZHAO, R.; WANG, C. Genetic analysis and QTL mapping of seed coat color in sesame (Sesamum indicum L.). PLOS One, v.8, e63898, 2013 .

Received on December 9, 2013 and accepted on March 17, 2014 